\title{
Phenotypic variability in byssus thread production of intertidal mussels induced by predators with different feeding strategies
}

\author{
Andrés U. Caro ${ }^{1,2}$, Joan Escobar ${ }^{2}$, Francisco Bozinovic ${ }^{1}$, Sergio A. Navarrete $^{1,2}$, \\ Juan Carlos Castilla ${ }^{1,2, *}$ \\ ${ }^{1}$ Center for Advanced Studies in Ecology \& Biodiversity (CASEB), Pontificia Universidad Católica de Chile, Alameda 340 , \\ PC 6513677, Santiago, Chile \\ ${ }^{2}$ Estación Costera de Investigaciones Marinas (ECIM), Departamento de Ecología, Facultad de Ciencias Biológicas, \\ Pontificia Universidad Católica de Chile, Alameda 340, PC 6513677, Santiago, Chile
}

\begin{abstract}
Predator-induced defenses have a significant influence on the expression of morphological and behavioral traits of marine species. In mussels, common responses to predators include thickening of the shell, enlargement of the adductor muscle and increases in byssus production. We hypothesize that predators with different feeding strategies have different effects on byssus production of the common intertidal mussels Perumytilus purpuratus and Semimytilus algosus in central Chile. Predators that dislodge prey mussels before killing them, such as crabs and seastars, should elicit increased byssus production in their prey compared to other predators such as whelks, which use different feeding mechanisms. Laboratory experiments with the seastar Heliaster helianthus, the crab Acanthocylus gayi, and the muricid gastropods Concholepas concholepas and Acanthina monodon showed that only A. gayi induced significant increases in byssus production, causing remarkably similar responses in both mussel species. Further experiments in which individual mussels with different attachment strengths were offered to A. gayi showed that the crabs first tried different mussels and then selected those with the weakest attachment, leading to consumption rates of weakly attached mussels that were 5 to 6 times higher than those of mussels with strong attachment to the substratum. Measurements of mussel attachment strengths in the field showed that, where A. gayi is abundant, both mussel species are more strongly attached than in habitats where this predator is scarce. While responses of mussels to crabs seem to be adaptive, the lack of a response to $H$. helianthus is intriguing, because it is one of the most important mussel predators in the system which can dislodge entire clumps of mussels at a time. It is possible that increased byssus production is ineffective in reducing predation by this large predator; however, this adaptive explanation requires further studies. These results highlight the predator-specific nature of many prey phenotypic responses and the importance of considering the multiplicity of predators typically present in most habitats.
\end{abstract}

KEY WORDS: Byssal thread production - Tenacity $\cdot$ Dislodgement $\cdot$ Predator-prey interaction Predator-induced defenses $\cdot$ Mussels $\cdot$ Sub-lethal effects

\section{INTRODUCTION}

Phenotypic plasticity is the property of a given genotype to produce different phenotypes in response to distinct environmental conditions (Pigliucci 2001, Piersma \& Drent 2003). This plasticity provides the potential for organisms to respond rapidly and effec- tively to change in internal or external environments. Hence, phenotypic plasticity can evolve if an organism's fitness is increased by changes in phenotype (Roff 1997, Agrawal 2001). Phenotypic plasticity may be essential for survival in variable environments, especially for sessile organisms (Pigliucci 2001). In fact, in patchy habitats, the ability of organisms to produce 
plastic responses will cost less than fixed responses. Predator-induced defenses are widespread examples of phenotypic plasticity in all major ecosystems. They involve changes in prey traits triggered by the perception of increased risks of mortality from predators or pathogens (Tollrian \& Harvell 1999).

In marine shores where predation is intense and plays a major role in controlling prey populations, prey species can exhibit a wide array of induced antipredator responses. These responses can be chemical (Cronin \& Hay 1996, Lindquist \& Hay 1996), morphological (Lively 1986a, Morgan 1989, Palmer 1990, Trussell \& Smith 2000) or behavioral (Sih 1997, Côté \& Jelnikar 1999, Soto et al. 2005), and frequently have an adaptive value because they increase the probability of survival when encountering a predator (Kerfoot \& Sih 1987, Baldwin 1996). Many different sub-lethal individual responses to predators have been documented in various mobile and sessile taxa, including limpets (Espóz \& Castilla 2000), barnacles (Lively 1986b, Lively et al. 2000), whelks (Appleton \& Palmer 1988, Trussell et al. 2006), seastars and sea urchins (Lawrence et al. 1999), littorinids (Keppel \& Scrosati 2004), and mussels (Leonard et al. 1999, Caro \& Castilla 2004). For mussels, which are usually exposed to a wide array of predators, including whelks, seastars, crabs, fishes and birds, the effectiveness of the type of response displayed is linked to the specific predator involved (Cheung et al. 2004). Indeed, different predators have different foraging strategies and these strategies may affect different structures of the mussel anatomy. For instance, several whelk species drill a hole through the mussel's shell to insert their proboscis and consume the tissue, while crabs dislodge the mussels from the substrate to crack them open (Elner 1978, Navarrete \& Castilla 1988). Clearly, a single defense mechanism would not be equally effective with both of these predators (Smith \& Jennings 2000, Freeman 2007). As expected, different studies have documented qualitatively different responses to predators in mussels, including (1) thickening of the shell to reduce predation by whelks and crabs (Leonard et al. 1999, Caro \& Castilla 2004, Freeman \& Byers 2006), (2) increased size of the adductor muscle to reduce predation by seastars (Reimer \& Tedengren 1996, Freeman 2007), (3) increased aggregation (clumping behaviour), forming of dense beds (Côté \& Jelnikar 1999, Nicastro et al. 2007), and increases in the strength of attachment to the substrate through increasing the rate of byssus thread production (Côté 1995, Cheung et al. 2004, 2006).

The mussel Perumytilus purpuratus (Lamarck, 1819) is the dominant competitor for primary space in midand low-intertidal zones of rocky shores in central southern Chile. This mussel can form extensive 3-dimensional aggregations that cover large areas at the mid-intertidal fringe at sites where recruitment is high and escape from predation is possible (Alvarado \& Castilla 1996, Guiñez \& Castilla 1999, Navarrete et al. 2005). The mussel Semimytilus algosus (Gould, 1850) is the second-most abundant intertidal mussel along the coast of Chile, occasionally reaching high abundances on the low shore, particularly in sandinundated, usually more wave-protected areas (Fernández et al. 2000). Field observations show that $P$. purpuratus exhibits a higher attachment strength to rock surfaces than $S$. algosus; a possible explanation for this difference is that the threads of $P$. purpuratus are significantly thicker than those of $S$. algosus (A. Caro unpubl. data). To date, we do not know the effect different predators may have on byssal thread production of these mussels. Both mussels are important prey for a diverse guild of predators, composed of the muricid gastropods Concholepas concholepas and Acanthina monodon (= Nucella crassilabrum), the seastar Heliaster helianthus and the decapod crabs Acanthocyclus gayi and A. hassleri (Castilla 1981, Castilla \& Paine 1987). This guild contains predators with different feeding strategies that could induce different changes in mussel byssus production rates. The whelks have 2 different mussel feeding strategies: (1) drilling a hole in the mussel shell (A. monodon and small $C$. concholepas) or (2) introducing the proboscis through a gap forced open between the valves using the foot muscles (juvenile and adult $C$. concholepas) (Castilla et al. 1979, Soto et al. 2004). The seastar $H$. helianthus uses its vascular system to force the valves open and then everts its cardiac stomach into the mussel paleal cavity (Tokeshi 1991). Usually, this seastar dislodges its prey before consumption (Navarrete \& Manzur 2008). Finally, crabs dislodge individual mussels from the substrate to crack the shell (Navarrete \& Castilla 1988). We hypothesized that dislodging predators induce a faster rate of byssus thread production than non-dislodging predators. Thus, crabs (A. gayi) and seastars ( $H$. helianthus) would be expected to induce higher byssus thread production in comparison to the 2 muricid gastropods. It is important to note that the expected response to predators is not correlated with the predators' relative importance in controlling mussel abundance. Indeed, C. concholepas and $H$. helianthus have far greater per capita and population effects on mussel mortality than A. gayi and A. monodon (Navarrete \& Castilla 2003, Soto et al. 2004).

In the present study, we quantified the attachment strength of 2 common intertidal mussels in habitats with different types and abundances of predators. In the laboratory, we experimentally evaluated the effect of effluents from the main mussel predators on the production of byssus threads to evaluate whether responses were similar between mussel species and 
whether they were stronger when facing dislodging predators (crabs and seastars) compared to nondislodging predators. Finally, through further experiments, we evaluated the potential adaptive value of these responses.

\section{MATERIALS AND METHODS}

Study site. Field surveys were conducted at Matanzas $\left(33^{\circ} 58^{\prime} \mathrm{S}, 71^{\circ} 53^{\prime} \mathrm{W}\right)$ in central Chile. The study area is characterized by small rocky outcrops and rocky shores of varying width (from a few to hundreds of meters) surrounded by sandy beaches. The most extensive uninterrupted rocky shores, hereafter called 'continuous platforms', are not covered with sand during the year because the rocky shore extends deeper into the subtidal zone. Small rocky outcrops (1 to $3 \mathrm{~m}^{2}$ in area), hereafter called 'emergent rocks', are periodically covered by sand on the low shore and always remain disconnected from other rocky shores. Both habitats are affected by moderate and roughly similar wave exposure (Caro \& Castilla 2004).

Both Perumytilus purpuratus and Semimytilus algosus were found on the rocky surfaces, but the abundances of mussel predators were different between habitats, presumably because the sand acts as a barrier to some predators' movement. A previous study at this site showed that the intertidal crab Acanthocyclus gayi is 10 times more abundant on the continuous platforms (6 ind. $\mathrm{m}^{-2}$ ) than on emergent rocks $\left(0.5\right.$ ind. $\left.\mathrm{m}^{-2}\right)$ (Caro \& Castilla 2004). In contrast, the whelk Acanthina monodon is more abundant on emergent rocks (10.3 ind $\mathrm{m}^{-2}$ ) than on continuous platforms (7.3 ind. $\mathrm{m}^{-2}$ ), while the gastropod Concholepas concholepas achieves similar abundances in both habitats (ca. 4 ind. $\mathrm{m}^{-2}$ ) (Caro \& Castilla 2004). The common seastar Heliaster helianthus is notably absent from all habitats at this locality (Navarrete et al. 2005), probably because this site is close to the southern geographic limit of the species. However, because it is a common and important predator of both mussel species at most locations (Navarrete \& Manzur 2008), H. helianthus was also considered in the laboratory experiments (see below).

Field measurements of attachment strength. In order to determine whether there were differences in mussel attachment strength between habitats, we measured the force required to dislodge mussels from the rock in December 2004. Attachment strength was quantified in 100 randomly selected individuals from each mussel species in each habitat. Following the method proposed by Bell \& Gosline (1997), we used a spring scale $\left(\right.$ Pesola $\left.^{\mathrm{TM}}\right)$ to measure the force required to dislodge an individual mussel from the rock when exerting a force perpendicular to the substratum. Each mussel was carefully held at the end of the spring scale with a metal clamp. To reduce the typically high variability in tenacity among individuals (Bell \& Gosline 1997), we measured attachment strength only for mussels between 15 and $25 \mathrm{~mm}$ shell length, attached directly to the rock surface and located in central positions within monolayer mussel beds. On some occasions, the exerted force removed more than one mussel, but these measurements were not included in the analyses.

Attachment strengths between habitats and mussel species were compared using a 2-way ANOVA with 'Mussel species' and 'Habitat' as fixed factors. Data were log transformed to meet assumptions of normality and homoscedasticity.

Predator-induced byssus thread production. A laboratory experiment was carried out to evaluate the effect of water-borne effluents (cues) from 4 different predator species on the byssal production rate of both mussel species. As indicated earlier, the 4 predator species used in the experiment have contrasting feeding strategies, allowing us to evaluate the effect of those strategies on byssus production. During the first week of January 2004, predators and mussels used in the experiment were collected at Matanzas (except for Heliaster helianthus individuals, which were collected at Las Cruces) and transported to the laboratory at the Estación Costera de Investigaciones Marinas (ECIM) at Las Cruces. In the lab, each species was maintained in separate aquaria with continuous seawater flow (ca. $20 \mathrm{l} \mathrm{h}^{-1}$ ) and aeration. Predators were held for $1 \mathrm{wk}$ without food, in order to eliminate the presence of other prey in their stomachs. Mussels were carefully cleaned of epibionts and byssus threads were removed.

The basic experimental unit consisted of a single predator contained in a small aquarium tank (2.5 l) connected via a plastic hose (internal diameter $=3 \mathrm{~mm}$ ) to a plastic Petri dish with an individual Perumytilus purpuratus or Semimytilus algosus experimental mussel (shell length 20 to $30 \mathrm{~mm}$ ). During the experiment, mussels received constant seawater flow $\left(1 \mathrm{l} \mathrm{h}^{-1}\right)$ exclusively from the predator aquarium, but at no time were they in direct contact with the predators. A total of 100 experimental units for each mussel species were set up. Twenty each of the 100 units were randomly assigned to the 4 predator treatments, and 20 additional experimental units were maintained without predators as a 'control' for changes in byssus production unrelated to predator cues. The total weight of predators in each aquarium was to $200 \mathrm{~g}$ wet weight. The experiment was carried out first for $S$. algosus and then for P. purpuratus in a completely randomized design.

Previous studies showed that mussels can adjust byssus production rates within minutes to hours of exposure to predator cues (Côté 1995). Therefore, to examine fast responses following the detection of preda- 
tors, the experiment was run for $4 \mathrm{~h}$. Every hour, 5 experimental units per treatment were randomly chosen, and the number of byssus threads produced by the experimental mussel was counted using a dissection scope. This design allowed us to examine whether the prey response was similar across predator treatments and whether the number of additional byssus threads produced quickly reached a maximum level. Because a different group of units was used each hour, time was considered as an orthogonal fixed factor. The byssal production rate was analyzed using 3-way factorial ANOVA, with 'Time', 'Predator treatment' and 'Mussel species' as fixed factors. Data were log-transformed to satisfy normality and variance homogeneity assumptions. Planned orthogonal contrasts were performed to test specific hypotheses related to the different feeding strategies of the predators. Thus, a first contrast tested whether non-dislodging predators (Acanthina monodon and Concholepas concholepas) changed the byssus production rate relative to controls (no predator effluent). The second contrast was performed to assess whether the presence of dislodging predators (i.e. Acanthocyclus gayi and Heliaster helianthus) increased byssus production of prey relative to controls. We then tested whether there were differences between the 2 dislodging predators (A. gayi versus $H$. helianthus). Finally, we tested whether byssus production of $H$. helianthus by itself differed from controls. Together, these contrasts evaluated whether mussels recognize the 2 different types of predators or whether the response is species-specific to that predator.

Susceptibility to crab predation. To evaluate whether the observed changes in byssus thread production are effective in reducing predation rates, we designed a multiple choice prey-preference experiment with Acanthocyclus gayi, the predator species that elicited a significant response in mussel byssus production (see 'Results'). In March 2005, we collected 100 adults each of Perumytilus purpuratus and Semimytilus algosus from the mid-intertidal fringe of Matanzas, brought them to the laboratory and maintained them for $48 \mathrm{~h}$ with circulating seawater and aeration in separate aquaria. Following this, the distal end of the foot (with the byssus gland) was cut off each individual under a dissection scope, preventing mussels from producing byssus threads during the experiment. Experimental mussels were then fixed to the substratum using fastdry glue (Poxipol ${ }^{\mathrm{TM}}$ ). Three levels of experimental attachment strength, (1) weak attachment, (2) intermediate attachment and (3) strong attachment, were generated by gluing individual mussels to pinheads of varying surface areas. The strong attachment treatment was produced with pinheads of ca. $7.07 \mathrm{~mm}^{2}$ surface, the intermediate strength was obtained using pinheads of ca. $3.14 \mathrm{~mm}^{2}$ surface area and the weak attachment using pinheads of ca. $0.79 \mathrm{~mm}^{2}$. To quantify the actual tenacity achieved by our procedure, we measured the force necessary to dislodge a mussel from the pinhead, using the same method described above for the field. This preliminary study used 20 specimens of each mussel species and attachment strength treatment and corroborated that the artificial attachment procedure produced a range of tenacities similar to that registered in the field: (1) weak attachment: $1.32 \mathrm{~kg} \pm 0.84,(2)$ intermediate attachment: $2.04 \mathrm{~kg} \pm 1.42$ and (3) strong attachment: $2.98 \mathrm{~kg} \pm 1.54$ (mean $\pm 1 \mathrm{SD}$ ). This manipulative approach permitted us to maintain a constant attachment strength for each experimental attachment strength level during the experiment, and at the same time ensured a spatial interspersion of individuals within the experimental arenas. This could not be achieved with mussels naturally generating byssus threads.

The basic experimental unit consisted of 5 mussels each of the 3 attachment strength treatments, which were offered to an adult crab simultaneously. Mussels were randomly arrayed in a $3 \times 5$ points matrix on an acrylic plate $(40 \times 30 \times 7 \mathrm{~cm})$ and fixed with pins. Eight independent plates (replicates) were used for each mussel species, and a constant seawater flow was maintained during the experiment. Prior to the experiment, predatory crabs were starved for $48 \mathrm{~h}$ to standardize hunger level. The experiment was conducted for $12 \mathrm{~h}$ in the dark because Acanthocyclus gayi exhibit nocturnal foraging activity (Navarrete \& Castilla 1988). At the end of the experiment, we quantified the number of specimens of each mussel species eaten in each of the 3 attachment strength treatments. We only counted individuals that were completely dislodged from the pinhead. Many authors have discussed the statistical analysis of multiple-choice preypreference experiments (Peterson \& Renaud 1989, Roa 1992, Prince et al. 2004). In the present study, we followed the method proposed by Prince et al. (2004) using a Hotelling's T-squared test for statistical analysis of prey-preference data.

\section{RESULTS}

\section{Field measurements of attachment strength}

Significantly higher tenacities were observed in the continuous platform habitat than on the emergent rocks (ANOVA: $F_{1,396}=25.85, \mathrm{p}<0.001$; Fig. 1). Moreover, Perumytilus purpuratus showed higher tenacity than Semimytilus algosus (ANOVA: $F_{1,396}=23.40, \mathrm{p}<$ 0.001; Fig. 1), and this difference was consistent across habitats (non-significant Habitat $\times$ Mussel species interaction, ANOVA: $F_{1,396}=0.02, \mathrm{p}=0.876$ ). 


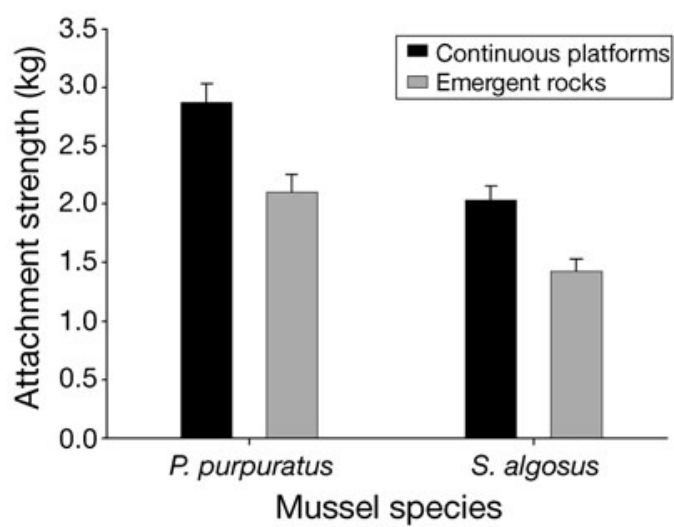

Fig. 1. Perumytilus purpuratus and Semimytilus algosus. Attachment strength of 2 intertidal mussels measured in 2 habitats: platforms and emergent rocks (means $+1 \mathrm{SE}, \mathrm{n}=100$ )

\section{Predator-induced byssus thread production}

Both mussel species produced byssus threads from the beginning of the experiment, and the total number of threads produced within each predator treatment increased at a constant rate throughout the experiment. Thus, the main factor Time and its interactions with other factors showed no statistically significant differences in byssus production rates (Table 1). Across predator treatments, the rate of byssus production was $1.16 \pm 0.04$ threads $\mathrm{h}^{-1}$ (mean $\pm \mathrm{SE}$ ) for Semimytilus algosus and 0.91 \pm 0.06 threads $\mathrm{h}^{-1}$ for Perumytilus purpuratus, and this difference was statistically significant (Table 1, Fig. 2).

Table 1. Perumytilus purpuratus and Semimytilus algosus. Three-way ANOVA on rate of byssus thread production in water-borne cue experiment with Time $(\mathrm{T})$, Predator Treatment (PT) and Mussel species (M) as fixed factors, and planned contrast for PT factor (predators: Acanthina monodon, Acanthocyclus gayi, Concholepas concholepas, Heliaster helianthus). df: degrees of freedom, SS: sum of squares, $F$ : value of $F$-statistics, p: p-value

\begin{tabular}{|lrrrr|}
\hline & df & SS & $F$ & $\mathrm{p}$ \\
\hline Source of variation & & & & \\
$\mathrm{T}$ & 3 & 0.03 & 0.98 & 0.406 \\
$\mathrm{PT}$ & 4 & 0.313 & 9.01 & $<0.001$ \\
$\mathrm{M}$ & 1 & 0.114 & 13.12 & $<0.001$ \\
$\mathrm{~T} \times \mathrm{PT}$ & 12 & 0.019 & 0.18 & 0.999 \\
$\mathrm{P} \times \mathrm{M}$ & 4 & 0.015 & 0.43 & 0.786 \\
$\mathrm{~T} \times \mathrm{M}$ & 3 & 0.028 & 1.09 & 0.354 \\
$\mathrm{~T} \times \mathrm{PT} \times \mathrm{M}$ & 12 & 0.026 & 0.25 & 0.995 \\
Error & 160 & 1.388 & & \\
Contrast & & & & \\
A. monodon/C. concholepas & 1 & $<0.01$ & $<0.01$ & 0.953 \\
$\quad$ vs. control & & & & \\
A. gayi/ H. helianthus & 1 & 0.04 & 5.07 & 0.026 \\
$\quad$ vs. control & & & & \\
H. helianthus vs. control & 1 & $<0.01$ & 0.39 & 0.531 \\
A. gayi vs. H. helianthus & 1 & 0.23 & 26.57 & $<0.001$ \\
\hline
\end{tabular}

We found highly significant differences in the rate of byssal production among predator treatments (Fig. 2, Table 1), and the predator-mediated response was similar in both mussel species (Table 1, non-significant interaction term Mussel species $\times$ Treatment). A planned contrast between the 2 non-disloging predators (Acanthina monodon and Concholepas concholepas) versus the control treatment showed that these predators do not change the rate of byssus production in mussels (Fig. 2, Table 1). In contrast, the average rate of byssus production of mussels exposed to dislodging predators (Acanthocyclus gayi and H. helianthus) was significantly higher than in controls (Table 1). However, further planned comparisons between these 2 types of predators showed significant differences between them, because the response induced by Heliaster helianthus was not different from the control treatment (Table 1). Thus, the crab A. gayi is the only predator that had a significant effect on the rate of byssus production in intertidal mussels (Fig. 2), suggesting that this defensive response is predatorspecific and not linked to the feeding mechanism used.

\section{Susceptibility to crab predation}

In experiments with Perumytilus purpuratus, the crab Acanthocyclus gayi displayed significant preferences for mussels with the weakest attachment strength followed by the intermediate strength treatment, and the least-consumed mussels were those with strong attach-

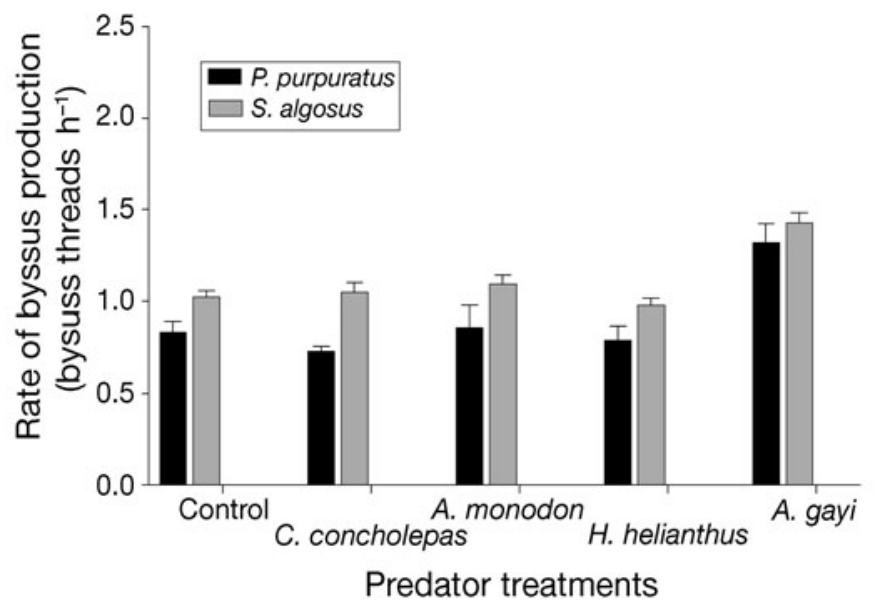

Fig. 2. Perumytilus purpuratus and Semimytilus algosus. Rate of byssus thread production (expressed as threads $\mathrm{h}^{-1}$ ) by $P$. purpuratus and $S$. algosus induced by water-borne cues from 4 predator species: Concholepas concholepas, Acanthina monodon, Heliaster helianthus and Acanthocyclus gayi, and compared to a control treatment (without predator) (means +1 $\mathrm{SE}, \mathrm{n}=5$ ). Since no significant difference in the Time factor or its interactions was found (see Table 1), the bars are averages for the $4 \mathrm{~h}$ experiment 


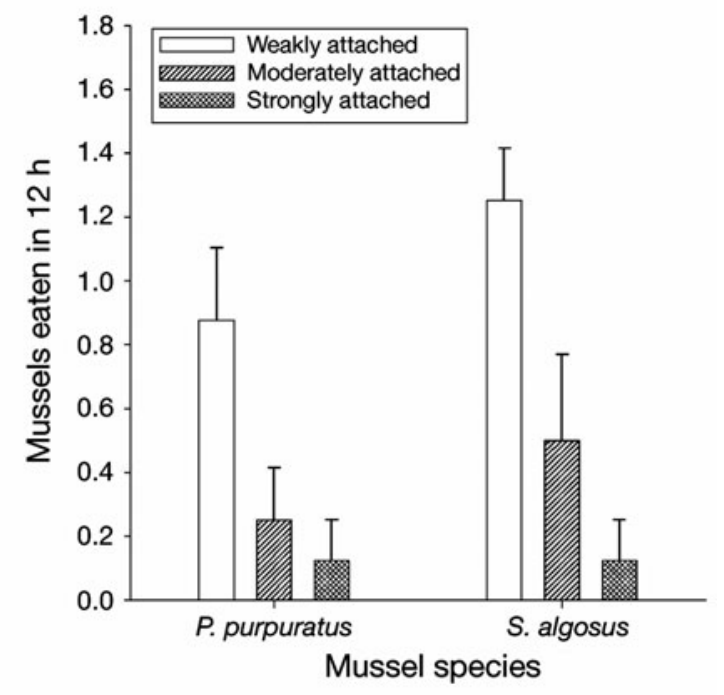

Fig. 3. Perumytilus purpuratus and Semimytilus algosus. Consumption rate of the crab Acanthocyclus gayi in multiplechoice feeding-preference experiment with 2 mussel species and 3 levels of experimental attachment strength (means +1 $\mathrm{SE}, \mathrm{n}=100$ )

ment to the substratum (Hotelling's T-squared $=134.03$, $\mathrm{p}<0.001$; Fig. 3). The mean consumption rate of weakly attached $P$. purpuratus mussels was 0.9 ind. $12 \mathrm{~h}^{-1}$, a rate 5 times higher than that for strongly attached mussels (Fig. 3). A remarkably similar pattern was observed for crabs feeding on Semimytilus algosus of different attachment strengths. Crabs showed a significant preference for mussels with weaker byssal attachment, which they consumed at a rate 6 times higher than that of strongly attached mussels (Fig. 3, Hotelling's T-squared $=167.00, \mathrm{p}<0.001$; Fig. 3 ).

\section{DISCUSSION}

Defenses induced in response to changing biotic environments can be an important adaptive attribute since they may increase individual reproductive success by reducing the per capita risk of predation. The adaptive value of such response depends, among other factors, on the ability to correctly recognize the threat and on the effectiveness of the response in reducing predation risk. The present study provides laboratory experimental evidence of remarkably similar phenotypic plasticity in byssus production rates of 2 common intertidal mussel species, induced by a specific predator, the crab Acanthocyclus gayi, and not by other abundant mussel predators. Further experiments showed that increased byssus production can indeed reduce the predation pressure by crabs, which indicates that this response may be adaptive. Moreover, field observations suggest that such differences in mussel attachment strengths occur in habitats with different predator assemblages. However, the seastar Heliaster helianthus, an important mussel predator that also regularly dislodges mussels to consume them, did not induce increased byssus production in either of the mussel species examined here.

Production of byssus threads and clumping in the mussel Mytilus edulis has been shown to be enhanced by exposure to crab effluents (Côté 1995, Côté \& Jelnikar 1999). These authors suggest that the adaptive value of these responses is in the reduced predation risk, because increased attachment strength to the substrate or to conspecifics makes it difficult for predators to manipulate and remove their prey. The present study shows that the common, coexisting mussels Semimytilus algosus and Perumytilus purpuratus significantly and rapidly $(<1 \mathrm{~h})$ increase the rate of byssus thread production in response to effluents from Acanthocyclus gayi. Within $4 \mathrm{~h}$, this predator induced a $43.3 \%$ increase in the number of threads produced compared to non-exposed individuals. These quick responses to predator effluents could be effective in reducing predation risk in the field. Our experiments show that only a few minutes elapse between the detection of the predator by the mussel and the development of this response. It is likely that mussels can produce a few additional byssus threads before being attacked by a crab. Thus, mussels inside or near galleries of A. gayi may produce more threads than those located further away. Our prey-preference experiments show that an increase in byssus thread production is an effective strategy to reduce the risk of predation by this crab species, because the increased attachment strength strongly influenced prey preferences and led to decreased feeding rates of the crab. When faced with mussels that are strongly attached to the substratum, crabs usually abandoned the prey and tested other nearby prey individuals, concentrating on those that were more easily removed from the substratum, which were later broken and consumed. The prey response to predators exhibited by the 2 most common mussel species in Chile examined here was similar, and also confirms results reported by Côté (1995) for Cancer pagurus feeding on $M$. edulis, suggesting that this is a generalized behavioral response of mytilids when facing the risk of predation by crabs. Since laboratory studies estimated that the metabolic cost of byssal thread production can represent up to $8 \%$ of a mussel's monthly energy expenditure (Hawkins \& Bayne 1985), rapid and specific plastic responses in the face of risk should be favored by selection (Tollrian \& Harvell 1999).

In intertidal mussels, increased byssus thread production seems to be a highly specific response to crabs. Effluents from other predators, such as the gastropods Acanthina monodon and Concholepas concholepas, and the seastar Heliaster helianthus did not cause a response 
in byssus production. While increased byssus thread production by the mussels may not be expected when they are faced with A. monodon or C. concholepas, considering the (non-disloging) feeding mechanisms employed by these predators, the lack of response to $H$. helianthus is surprising and contrary to our expectations. First, this seastar is one of the most important mussel predators in Chile, with per capita and total consumption rates much higher than crabs (Paine et al. 1985, Navarrete \& Castilla 2003). Second, this species usually removes entire clumps of juvenile and adult mussels from the substratum before consuming them (Castilla 1981, Navarrete \& Manzur 2008). A preliminary laboratory experiment showed that the lack of response (byssus production) by mussels to $H$. helianthus effluents occurs at multiple sites along hundreds of kilometers in central Chile (authors' unpubl. data). Thus, it is unclear why mussels respond so quickly to crabs but not to the much larger and voracious seastar. Field observations and preliminary laboratory experiments suggest that the force exerted by seastars on mussels can greatly exceed the tenacity of even the most firmly attached individuals. Moreover, seastars usually remove entire clumps of the mussel bed in a single foraging bout (Navarrete \& Manzur 2008). Therefore, an adaptive explanation to the lack of response to $H$. helianthus effluents may be that, while mussels detected this predator, any increment in tenacity is not effective in reducing predation against this predator species. Further studies are needed to evaluate this proposition.

While some prey responses to predation risk might be generic, and the same response might work well for a wide variety of predators, others can only defend themselves against particular predators with particular attachment or feeding modes. It is therefore important to determine which type of responses are induced by different predators, and how different species of predators in turn are affected by the induced defenses of their prey (Adler \& Harvell 1990, Ruxton et al. 2004). Indeed, most prey regularly face multiple predators in the field and, depending on the types of predators, generalized responses could be less effective or more costly energetically than predator-specific responses. It is difficult to determine whether such responses are observable under field conditions, and over which spatial scales they should be studied, especially in high-energy environments such as wave-swept rocky shores. Our estimates of attachment strengths in the field suggest that persistent differences in tenacity between habitats could be the result of local differences in the composition and abundance of the predator assemblage, in particular considering the absence of predatory crabs from some areas. But these differences in mussel attachment could also be produced by abiotic differences between habitats. Measurements of attachment strength also showed wide variation among individuals, as is to be expected from plastic, reversible responses. For instance, in continuous platform habitats, where crab predators are more abundant and mussels are generally more strongly attached, there were still 15 to $20 \%$ weakly attached individuals that could be selected by Acanthocyclus gayi as prey.

In conclusion, the present study provides experimental evidence for the different anti-predation behavioral responses exhibited by intertidal mussels, their specificity to different predators and their potential adaptive value. At the same time, our results open up new questions regarding the lack of response to predators that are expected to elicit a response. Finally, we highlight the importance of considering the multiplicity of predation threats faced by intertidal prey, and particularly of evaluating how predators are influenced by predator-induced defenses in natural communities.

Acknowledgements. We thank V. Gutiérrez, A. Delgado and L. Prado for field and laboratory assistance. B. Kelaher, P. Manríquez, J. Shinen and 4 reviewers suggested modifications to this manuscript. This work was supported by funds from the Pew Charitable Trust to J.C.C. The paper was completed during the tenure of FONDAP grant 1501-0001 to J.C.C., S.A.N. and F.B. A.U.C. was supported by a CONICYT doctoral scholarship and the Andrew Mellon Foundation.

\section{LITERATURE CITED}

> Adler FR, Harvell CD (1990) Inducible defenses, phenotypic variability and biotic environments. Trends Ecol Evol 5: 407-410

Agrawal AA (2001) Phenotypic plasticity in the interactions and evolution of species. Science 294:321-326

Alvarado JL, Castilla JC (1996) Tridimensional matrices of Perumytilus purpuratus on intertidal platforms with varying wave forces in central Chile. Mar Ecol Prog Ser 133: 135-141

Appleton RD, Palmer AR (1988) Water-borne stimuli released by predatory crabs and damaged prey induce more predator-resistant shells in a marine gastropod. Proc Natl Acad Sci USA 85:4387-4391

Baldwin IT (1996) Inducible defenses and population biology. Trends Ecol Evol 11:104-105

Bell EC, Gosline JM (1997) Strategies for life in flow: tenacity, morphometry, and probability of dislodgment of two $M Y-$ tilus species. Mar Ecol Prog Ser 159:197-208

Caro AU, Castilla JC (2004) Predator-inducible defences and local intrapopulation variability of the intertidal mussel Semimytilus algosus in central Chile. Mar Ecol Prog Ser 276:115-123

Castilla JC (1981) Perspectivas de investigación en estructura y dinámica de comunidades intermareales rocosas de Chile central. II. Depredadores de alto nivel trófico. Medio Ambiente (Chile) 5:190-215

Castilla JC, Paine RT (1987) Predation and community organization on Eastern Pacific, temperate zone, rocky intertidal shores. Rev Chil Hist Nat 60:131-151

Castilla JC, Guisado C, Cancino J (1979) Aspectos ecológicos y conductuales relacionados con la alimentación de Concholepas concholepas (Mollusca: Gastropoda: Muricidae). Biol Pesq 12:99-114 
Cheung SG, Tong PY, Yip KM, Shin PKS (2004) Chemical cues from predators and damaged conspecifics affect byssus production in the green-lipped mussel Perna viridis. Mar Freshw Behav Physiol 37:127-135

Cheung SG, Luk KC, Shin PKS (2006) Predator-labeling effect on byssus production in marine mussels Perna viridis (L.) and Brachidontes variabilis (Krauss). J Chem Ecol 32:1501-1512

> Côté IM (1995) Effects of predatory crab effluents on byssus production in mussels. J Exp Mar Biol Ecol 188:233-241

> Côté IM, Jelnikar E (1999) Predator-induced clumping behaviour in mussels (Mytilus edulis Linnaeus). J Exp Mar Biol Ecol 235:201-211

Cronin G, Hay ME (1996) Induction of seaweed chemical defenses by amphipod grazing. Ecology 77:2287-2301

Elner RW (1978) The mechanics of predation by the shore crab, Carcinus maenas (L.) on the edible mussel Mytilus edulis L. Oecologia 36:333-344

Espóz C, Castilla JC (2000) Escape responses of four intertidal limpets to seastars. Mar Biol 137:887-892

Fernández M, Jaramillo E, Marquet PA, Moreno CA and others (2000) Diversity, ecology and biogeography of nearshore benthic ecosystems: an overview and needs for conservation. Rev Chil Hist Nat 73:629-662

Freeman AS (2007) Specificity of induced defenses in Mytilus edulis and asymmetrical predator deterrence. Mar Ecol Prog Ser 334:145-153

Freeman AS, Byers JE (2006) Divergent induced responses to an invasive predator in marine mussel populations. Science 313:831-833

Guiñez R, Castilla JC (1999) A tridimensional self-thinning model for multilayered intertidal mussels. Am Nat 154: 341-357

> Hawkins AJS, Bayne BL (1985) Seasonal variation in the relative utilization of carbon and nitrogen by the mussel Mytilus edulis: budgets, conversion efficiencies and maintenance requirements. Mar Ecol Prog Ser 25:181-18

Keppel E, Scrosati R (2004) Chemically mediated avoidance of Hemigrapsus nudus (Crustacea) by Littorinia scutulata (Gastropoda): effects of species coexistence and variable cues. Anim Behav 68:915-920

Kerfoot WC, Sih A (1987) Predation. Direct and indirect impacts on aquatic communities. University Press of New England, Hanover

Lawrence JM, Byrne M, Harris L, Keegan B, Freeman S, Colwell BC (1999) Sublethal arm loss in Asterias amurensis, $A$ rubens, A vulgaris, and A forbesi (Echinodermata: Asteroidea). Vie Milieu 49:29-80

Leonard GH, Bertness MD, Yund PO (1999) Crab predation, waterborne cues, and inducible defenses in the blue mussel, Mytilus edulis. Ecology 80:1-14

Lindquist N, Hay M (1996) Palatability and chemical defense of marine invertebrate larvae. Ecol Monogr 66:431-450

Lively CM (1986a) Competition, comparative life histories, and maintenance of shell dimorphism in a barnacle. Ecology 67:858-864

Lively CM (1986b) Predator-induced shell dimorphism in the acorn barnacle Chthamalus anisopoma. Evolution 40: $232-242$

Lively CM, Hazel WN, Schellenberger MJ, Michelson KS (2000) Predator-induced defense: variation for inducibility in an intertidal barnacle. Ecology 81:1240-1247

> Morgan SG (1989) Adaptive significance of spination in estuarine crab zoeae. Ecology 70:464-482

> Navarrete SA, Castilla JC (1988) Foraging activities of Chilean intertidal crabs Acanthocyclus gayi Milne-Edwards et Lucas and A. hassleri Rathbun. J Exp Mar Biol Ecol 118:115-136

Navarrete SA, Castilla JC (2003) Experimental determination

Editorial responsibility: Roger Hughes,

Bangor, UK of predation intensity in an intertidal predator guild: dominant versus subordinate prey. Oikos 100:251-262

Navarrete SA, Manzur T (2008) Individual- and populationlevel responses of a keystone intertidal predator to variation in prey productivity over geographic scales. Ecology 89:2005-2018

Navarrete SA, Wieters E, Broitman B, Castilla JC (2005) Scales of benthic-pelagic coupling and the intensity of species interactions: from recruitment limitation to top down control. Proc Natl Acad Sci USA 102:18046-18051

> Nicastro KR, Zardi GI, McQuaid CD (2007) Behavioural response of invasive Mytilus galloprovincialis and indigenous Perna perna mussels exposed to risk of predation. Mar Ecol Prog Ser 336:169-175

> Paine RT, Castilla JC, Cancino J (1985) Perturbation and recovery patterns of starfish-dominated intertidal assemblages in Chile, New Zealand, and Washington State. Am Nat 125:679-691

Palmer AR (1990) Effect of crab effluent and scent of damaged conspecifics on feeding, growth, and shell morphology of the Atlantic dogwhelk Nucella lapillus. Hydrobiologia 193:155-182

Peterson CH, Renaud PE (1989) Analysis of feeding preference experiments. Oecologia 80:82-86

Piersma T, Drent J (2003) Phenotypic flexibility and the evolution of organismal design. Trends Ecol Evol 18:228-233

Pigliucci M (2001) Phenotypic plasticity: beyond nature and nurture. The Johns Hopkins University Press, Baltimore, MD

> Prince JS, LeBlanc WG, Macia S (2004) Design and analysis of multiple choice feeding preference data. Oecologia 138: $1-4$

> Reimer O, Tedengren M (1996) Phenotypical improvement of morphological defences in the mussel Mytilus edulis induced by exposure to the predator Asterias rubens. Oikos 75:383-390

Roa R (1992) Design and analysis of multiple-choice feedingpreference experiments. Oecologia 89:509-515

Roff DA (1997) Evolutionary quantitative genetics. Chapman \& Hall, New York

Ruxton GD, Sherratt TN, Speed MP (2004) Avoiding attack. The evolutionary ecology of crypsis, warning signals and mimicry. Oxford University Press, Oxford

Sih A (1997) To hide or not to hide? Refuge use in a fluctuating environment. Trends Ecol Evol 12:375-376

Smith LD, Jennings JA (2000) Induced defensive responses by the bivalve Mytilus edulis to predators with different attack modes. Mar Biol 136:461-469

Soto R, Castilla JC, Bozinovic F (2004) Foraging behavior of the gastropod Acanthina monodon Pallas, 1774 (Gastropoda: Muricidae) in the intertidal rocky shores of central Chile. Rev Chil Hist Nat 77:157-175

Soto R, Castilla JC, Bozinovic F (2005) The impact of physiological demands on foraging decisions under predation risk: a test with the whelk Acanthina monodon. Ethology 111:1044-1049

Tokeshi M (1991) Extraoral and intraoral feeding - flexible foraging tactics in the South American sunstar, Heliaster helianthus. J Zool 225:439-447

Tollrian R, Harvell CD (1999) The ecology and evolution of inducible defenses. Princeton University Press, Princeton, NJ

> Trussell GC, Smith LD (2000) Induced defenses in response to an invading crab predator: an explanation of historical and geographic phenotypic change. Proc Natl Acad Sci USA 97:2123-2127

Trussell GC, Ewanchuk PJ, Matassa CM (2006) Habitat effects on the relative importance of trait- and densitymediated indirect interactions. Ecol Lett 9:1245-1252

Submitted: November 28, 2007; Accepted: August 14, 2008

Proofs received from author(s): November 18, 2008 